\title{
ADAPTIVE CAPABILITY OF CORN HYBRIDS WITH DIFFERENT METHODS OF WATERING AND MOISTURE SUPPLY IN THE ARID STEPPE OF UKRAINE
}

\author{
Ivaniv M. O., Lavrynenko Yu. O.
}

\section{INTRODUCTION}

In recent decades, the yield of cereals worldwide has increased significantly. The increase in yield was mainly due to selection and genetic improvement of varietal composition, increasing the productivity potential of genotypes, adaptability to variability of agroecological factors, tolerance to stressors of biotic and abiotic origin. This emphasizes the importance of the main direction in increasing productivity of breeding and genetic development, which according to leading scientists provide the main increase in yield and gross harvest in recent years ${ }^{1,2}$.

Ukraine has a strong potential for grain production. Therefore, today an important area of scientific support of crop production is the creation of highly adaptive varieties and hybrids of agroecological orientation with a high degree of genetic protection of the crop from biotic and abiotic environmental factors, development of scientific bases for genetically programmed varieties and hybrids of given biological and economic orientation ${ }^{3,4}$.

Ukraine intends and has the opportunity to take an honorable place among the world's leading developed countries in terms of economic performance of the agricultural sector and has already established itself as a powerful producer and exporter of corn grain. The rapid growth rate of corn production is due to the extremely high positive response to genetic changes and technological developments ${ }^{5,6}$.

Ukrainian breeders have created corn hybrids with a certain level of adaptability to specific agro-ecological zones and technologies. The

\footnotetext{
1 Tester M., Langridge P. Breeding technologies to increase crop production in a changing World. Science. 2010. Vol. 327, Iss. 5967. P. 818-822. DOI : 10.1126/science.1183700.

${ }^{2}$ Gilliham M., Able J.A., Roy S.J. Translating knowledge about abiotic stress tolerance to breeding programmers. Plant Journal. 2017. Vol. 90, Iss. 5. P. 898-917. DOI : 10.1111/tpj.13456.

${ }^{3}$ Гадзало Я.М., Гладій М.В., Саблук П.Т., Лузан Ю.Я. Розвиток агарної сфери економіки в умовах децентралізації управління в Україні. Київ : Аграрна наука, 2018. 328 с.

${ }^{4}$ Productivity and adaptability of Myronivka spring barley varieties of different breeding periods / В.М. Гудзенко та ін. Plant Varieties Studying and Protection. 2018. № 14(2). C. 190-202. DOI : org/10.21498/2518-1017.14.2.2018.134766.

5 Дзюбецький Б.В., Черчель В.Ю. Урожайність зерна скоростиглих гібридів кукурудзи різних сортозмін. Вісник аграрної науки. 2017. № 8. С. 19-23.

${ }^{6}$ Марченко Т.Ю., Нужна М.В., Боденко Н.А. Моделі гібридів кукурудзи FАO 150-490 для умов зрошення. Plant Varieties Studying and Protection. 2018. T. 14. № 1. C. 58-64. DOI :10.21498/25181017.14.1.2018.126508.
} 
introduction of new generation hybrids has made it possible to increase grain yields in recent decades from $2.62 \mathrm{t} / \mathrm{ha}$ to $7.80 \mathrm{t} / \mathrm{ha}$. In terms of grain yield, Ukraine in 2018-2019 was ahead of the European Union. It should be noted that such yields do not yet meet the potential of modern hybrids, but among the world's major producers of corn grain, Ukraine ranks third. Thanks to the introduction of innovative hybrids, Ukraine has entered the top six main producers of corn grain in the world and five exporters ${ }^{7,8}$.

The fundamental task of increasing yields and expanding the area of corn cultivation is the use of hybrids adapted to certain geographical areas and adapted to specific technologies. In this area of analytical research, models of adaptability, both in general in flora and fauna, and in breeding achievements of corn, are of paramount importance for the spread of crops in climatic zones, increasing their productivity, endurance, and in this sense, adaptive models are even provided advantages over heterosis performance models ${ }^{9}$.

An important role in increased yields and improved grain quality belongs to the correct selection of hybrids for cultivation. High-yielding hybrids remove a large amount of nutrients from the soil, consume a large amount of water, so such hybrids require appropriate agricultural techniques. In the absence of such conditions, a potentially more productive hybrid not only does not increase, but may yield in yield to another less productive, but also less demanding hybrid cultivation. That is why a differentiated approach to the production use of hybrids of the corresponding group of manufacturability with specific adaptability to agroecological factors is required ${ }^{10,11}$.

Land resources of the south of Ukraine are quite diverse in the structure of soil cover, rainfall, hydrothermal coefficient (HTC), the sum of effective temperatures, terrain. Within the southern region, two agro-ecological zones have been identified: the Southern Steppe (HTC V-IX 0.61-0.66) and the Arid Steppe (HTC V-IX 0.56-0.60] ${ }^{12}$. Therefore, despite the sufficiently high potential of soil fertility and thermal regime, the spread of corn is constrained by a lack of natural precipitation.

Artificial irrigation helps to increase production processes, improves the microclimate of the phytocenosis, promotes the efficient use of bioclimatic

\footnotetext{
7 Food and Agriculture Organization of the United Nations. URL : http://www.fao.org/faostat/ en/\#data/QC.

${ }^{8}$ United States Department of Agriculture. Foreign Agricultural Service. URL : http://www.usda crop explorer: global crop production analysis.

${ }^{9}$ Troyer A.F. Adaptedness and heterosis in corn and mule hybrids. Crop science. 2006. V. 46. № 2. P. 528-543. DOI :10.2135/cropsci2005.0065.

${ }^{10}$ Vozhegova R.A., Hlushko T.V. Productivity of maize hybrids of different fao groups depending on condition of irrigation and dosage of fertilizers in the southern steppe of Ukraine. Agricultural Science and Practice. 2014. № 1(3). P. 62-68.

${ }^{11}$ Оцінка показників стабільності й пластичності нових гібридів кукурудзи (Zea mays L.) в умовах Полісся та Степу України / Л.М. Присяжнюк та ін. Plant Varieties Studying and Protection. 2016. № 2. C. 16-21. DOI : 10.21498/2518-1017.2(31).2016.70050.

${ }^{12}$ Наукові основи агропромислового виробництва в зоні Степу України / М.В. Зубець та ін. Київ : Аграрна наука, 2010. 765 с.
} 
potential. Technologies for growing corn under different irrigation regimes have been developed, which allows to reveal the genotypic potential of hybrid productivity ${ }^{13}$.

Today in the south of Ukraine in production, along with traditional sprinklers, new methods of irrigation are introduced such as drip irrigation and ground irrigation. These irrigation methods have a high efficiency in adjusting the irrigation and feeding regimes, require less material costs (drip irrigation) and more reliable and long-lasting (ground irrigation). However, not all crops can be grown under such irrigation methods and no varietal (hybrid) response to such elements of technology has been established.

\section{Materials and methods of the research}

The research was conducted in accordance with the thematic research plan of the Kherson State Agrarian University under the task "Implementation of the technology of growing major crops". Field experiments were performed in the Agricultural Firm "Syvashke" Novotroitsk district of Kherson region, located in the agroecological zone Arid Steppe and within the Kakhovka irrigation system, in 2017-2019 in accordance with generally accepted methods ${ }^{14,15}$.

The aim of the research was to establish the yield structure and parameters of adaptability of modern domestic corn hybrids under different methods of irrigation and moisture in the Arid Steppe and to determine the dynamics of growth of grain yields in the south of Ukraine.

The object of research was modern maize hybrids of domestic selection of different maturity groups. Hybrids were sown by different irrigation methods (regular sprinkling, drip irrigation, ground irrigation) and without irrigation to compare their drought resistance. Characterization of genotype-environment interaction, differentiation of varieties by yield and stability was performed using the most common in world and domestic studies methods Eberhart S.A., Russell W.A. ${ }^{16}$. The coefficient of ecological plasticity $b_{i}$ and stability variant $S_{d i}^{2}$ were determined. The drought resistance coefficient was determined by the ratio of yield without watering to irrigation conditions. The methods of the research are field, laboratory, statistical and retrospective methods.

The soil of the experimental site is dark chestnut medium loamy slightly saline with deep groundwater levels. The arable horizon is in the range of

\footnotetext{
13 Assessment of the CROPWAT 8.0 software reliability for evapotranspiration and crop water requirements calculations / R.A. Vozhehova et al. Journal of Water and Land Development. Polish Academy of Sciences (PAN) in Warsaw. 2018. № 39 (X-XII). P. 147-152. DOI : 10.2478/jwld-2018-0070.

${ }^{14}$ Вожегова Р.А., Малярчук М.П., Коковіхін С.В. Методика польових і лабораторних досліджень на зрошуваних землях. Херсон : Грінь Д.С., 2014. 286 с.

${ }_{15}$ Ушкаренко В.О., Голобородько С.П., Коковіхін С.В. Методика польового досліду (зрошуване землеробство). Херсон : Грінь Д.С., 2014. 448 с.

16 Eberhart S.A., Russell W.A. Stability parameters for comparing varieties. Crop Science. 1966. Vol. 6. № 1. P. 36-40.
} 
0-30 cm. The lowest moisture content of $0.7 \mathrm{~m}$ of soil layer is $22.0 \%$, wilting moisture is $9.7 \%$ by weight of dry soil. The arable layer of soil contains $2.1 \%$ humus. Agricultural techniques for growing corn hybrids in the experiments were generally accepted for the southern part of Ukraine. The predecessor is soy.

The main criterion for planning the irrigation regime was the level of preirrigation soil moisture (LPSM), which was maintained at $80 \%$ of the lowest soil moisture content at all stages of organogenesis, and which is considered the biologically optimal irrigation regime for $\operatorname{corn}^{17}$.

\section{Research results and discussion}

In the arid steppe zone of Ukraine, against the background of trends in climate change, the realization of the potential productivity of corn hybrids is limited by various limited factors and one of the main is the moisture supply. Adaptation to soil and climatic conditions of the Arid Steppe zone, which is characterized by acute moisture deficit, high summer temperatures, long frostfree period is the main requirement for corn hybrids for non-irrigated agriculture. Under such climatic conditions, high and stable in space and time yields are able to provide hybrids only under irrigation conditions and specially created drought-resistant and heat-resistant hybrids.

Historically, selection achievements and agronomic measures have significantly increased yields in southern Ukraine. Retrospective analysis of the yield of major cereals in the steppe zone for the 130-year period, which was conducted on the base of the report "Historical essay on the activities of the Kherson Provincial Zemstvo for 1865-1899" 18 and statistics on the Kherson region, showed a significant increase in yield during this period (Table 1).

Table 1

\section{Comparative yield of grain crops in Kherson province and Kherson region for 130 years}

\begin{tabular}{|c|c|c|c|c|c|}
\hline \multirow[b]{2}{*}{ Culture } & \multicolumn{3}{|c|}{ Grain yield by years, c/ha } & \multirow{2}{*}{$\begin{array}{c}\text { Annual } \\
\text { increase in } \\
\text { yield, c/ha }\end{array}$} & \multirow{2}{*}{$\begin{array}{c}\text { Annual } \\
\text { increase in } \\
\text { yield under } \\
\text { irrigation, } \\
\text { c/ha }\end{array}$} \\
\hline & $\begin{array}{c}1887- \\
1891\end{array}$ & $\begin{array}{c}2017- \\
2018\end{array}$ & $\begin{array}{c}2017-2018 \\
\text { under } \\
\text { irrigation }\end{array}$ & & \\
\hline Winter wheat & 6,00 & 33,9 & 52,1 & 0,21 & 0,34 \\
\hline Barley & 5,76 & 26,5 & 55,2 & 0,16 & 0,36 \\
\hline Corn & 6,59 & 46,5 & 82,3 & 0,31 & 0,58 \\
\hline
\end{tabular}

Note: Yields for 1887-1891 were converted from poods to tithes to quintals per hectare

\footnotetext{
17 Науково-практичні рекомендації з технології вирощування кукурудзи в умовах зрошення Південного Степу України / Р.А. Вожегова та ін. Херсон : Грінь Д.С., 2015. 104 с.

18 Исторический очеркъ деятельности Херсонскаго Губернскаго Земства за $1865-1899$ гг. Выпускъ III. Издание Херсонсой Губернской земской Управы. Херсонъ, 1906. 276 с.
} 
The annual increase in the yield of the main grain crops (wheat and barley) was 21 and $16 \mathrm{~kg} / \mathrm{ha}$ per year. In wheat, the yield increased 5.65 times over 130 years and increased from 6.00 to $33.9 \mathrm{c} / \mathrm{ha}$. During this historical period, the technology of cultivation has achieved significant changes, irrigation was introduced in the Kherson region on an area of 432 thousand hectares. Winter wheat on irrigated lands had an even higher yield $52.1 \mathrm{c} / \mathrm{ha}$, which is 8.7 times higher than in the previous century. The highest rates of yield growth were recorded for corn. The annual increase in yield was $31 \mathrm{~kg} / \mathrm{ha}$ per year and this was due to the use of new varieties (hybrids) and improved cultivation technologies. Irrigation provided an opportunity to realize the potential yield of new hybrids and increase yields from 6.59 to $82.3 \mathrm{c} / \mathrm{ha}$. Yields increased 12.5 times with an annual increase of $58 \mathrm{~kg} / \mathrm{ha}$ per year.

Modern corn hybrids, created for irrigation conditions, must be provided to production with certain parameters of technological requirements. This is especially true of irrigation regimes and irrigation methods. Studies on determining the grain yield of domestic innovative corn hybrids under different methods of irrigation and without irrigation in the Arid Steppe made it possible to provide production parameters of adaptation of certain hybrids to specific agroecological and technological features. To establish the response rate of newly created hybrids to technological conditions, the effect of different irrigation methods on grain yield was investigated: irrigation with Zimatik sprinkler, drip irrigation, ground irrigation with pre-irrigation soil moisture level of $80 \% \mathrm{HB}$ in the soil layer $0-50 \mathrm{~cm}$. Hybrids without irrigation were sown to determine drought resistance and plasticity.

The Table 2 shows the productivity of modern maize hybrids depending on the method of irrigation and moisture in the Arid Steppe in the Kakhovka irrigation area.

Table 2

\section{Grain yield ( $t / h a)$ of corn hybrids under different irrigation methods} and without irrigation (2017-2019)

\begin{tabular}{|l|c|c|c|c|c|}
\hline \multicolumn{1}{|c|}{ Hybrid } & FAO & $\begin{array}{c}\text { Without } \\
\text { irrigation }\end{array}$ & $\begin{array}{c}\text { Irrigation } \\
\text { by sprinkling }\end{array}$ & $\begin{array}{c}\text { Watering } \\
\text { by drip } \\
\text { irrigation }\end{array}$ & $\begin{array}{c}\text { Irrigation } \\
\text { with subsoil } \\
\text { irrigation }\end{array}$ \\
\hline Stepovyi & 190 & 3,28 & 11,24 & 11,46 & 10,68 \\
\hline Pyvykha & 180 & 3,05 & 11,04 & 11,21 & 10,81 \\
\hline Skadovskyi & 290 & 2,57 & 11,34 & 11,41 & 10,12 \\
\hline Khotyn & 280 & 2,74 & 11,63 & 12,47 & 12,19 \\
\hline Kakhovskyi & 380 & 2,13 & 12,10 & 13,22 & 12,65 \\
\hline Rostok & 340 & 2,35 & 12,22 & 14,15 & 13,74 \\
\hline Arabat & 420 & 1,81 & 13,14 & 15,23 & 14,21 \\
\hline Sofia & 420 & 1,92 & 13,43 & 15,78 & 14,81 \\
\hline HIP & & 0,25 & 0,32 & 0,41 & 0,34 \\
\hline
\end{tabular}


It was found out that hybrids of FAO 180-290 (Stepovyi, Pyvykha, Skadovskyi), although they formed lower yields, but had the greatest stability under different irrigation methods in the range of 10.12-11.46 t/ha. Grain yields of early-maturing hybrids were the highest without irrigation of 3.28 and $3.05 \mathrm{t} / \mathrm{ha}$, which indicates their high drought resistance. The use of these hybrids is expedient under the conditions of water-saving irrigation regimes on irrigated lands with low hydromodule and on rainfed massifs.

Among the hybrids of the middle-early maturity group (FAO 280-290), the best yield was the hybrid Khotyn (FAO 280), regardless of the method of watering. Under drip irrigation, its yield was $12.47 \mathrm{t} / \mathrm{ha}$. Irrigation by sprinkling and subsoil irrigation reduced yields by 0.84 and $0.28 \mathrm{t} / \mathrm{ha}$, which is due to the greater opportunities for rapid wetting of the surface layer of the soil under drip irrigation during drought-critical growing seasons.

Hybrids of the medium-ripe group Kakhovskyi and DN Rostock also had the highest grain yield under drip irrigation 13.2 and $14.15 \mathrm{t} / \mathrm{ha}$. The decrease in yield under other irrigation methods ranged from 0.41 to $1.93 \mathrm{t} / \mathrm{ha}$. The greatest advantages of the drip irrigation method were recorded in the midlate hybrids Arabat and DN Sofia, for which the yield reached 15.23 and $15.78 \mathrm{t} / \mathrm{ha}$. Yields were higher by $1.02-2.35 \mathrm{t} / \mathrm{ha}$ compared to other irrigation methods. This reaction of medium-late hybrids with FAO 420-430 is explained by the fact that the moisture consumption of hybrids with a longer growing season by $70-80 \%$ is provided by irrigation water. During the period of the greatest evapotranpiration (July-August), the daily water consumption of corn in the Arid Steppe exceeds $100 \mathrm{~m}^{3} /$ ha and this amount of water can be provided by drip irrigation daily. Irrigation by sprinkling by installations of frontal or circular action can provide the next watering with the minimum term of 4-5 days that can be late and, as a result, the optimum level of humidity is broken. Irrigation by soil method is carried out by laying an irrigation tape to a depth of $30 \mathrm{~cm}$ of soil profile. Moistening of the surface layer of the soil is carried out by raising the irrigation water along the capillary border, which also does not provide the optimal level of moistening of the surface layer of the soil $0-10 \mathrm{~cm}$.

The lowest grain yield of hybrids was observed without irrigation. The difference in yield was 7.85-12.75 t/ha (Table 3). There was a clear relationship between drought resistance and maturity group of hybrids. The maximum yield without watering was recorded in early-maturing hybrids Stepovyi and DN Pyvykha (3.53 and 3.28 t ha) in 2018, which was more favorable in terms of precipitation. The minimum yield without irrigation was observed in the mid-late hybrids Arabat and Sofia 1.36 and $1.45 \mathrm{t} / \mathrm{ha}$.

The most objective and reliable assessment of the impact of drought on hybrids can be the ratio of their productivity on a natural background of moisture and optimal moisture. Comparison of yield indicators on two 
backgrounds is a criterion for the degree of resistance of corn hybrids to drought (drought resistance coefficient). The drought resistance coefficient was the highest in early-ripening and middle-early hybrids 0.22-0.29 (see Table 3). The drought resistance coefficient decreased sharply with increasing maturity of hybrids and was minimal in Arabat and Sofia hybrids 0.13. However, these hybrids recorded the highest grain yield under drip irrigation 16.04 and $16.43 \mathrm{t} / \mathrm{ha}$, respectively. These hybrids have the greatest yield potential and a strong genotype-environmental response to moisture. This is confirmed by calculations of the parameters of plasticity and stability. The parameters of ecological plasticity $\left(b_{i}\right)$ and stability of the reaction to the ecogradient $\left(S_{d i}^{2}\right)$ were calculated to classify the varieties according to their suitability for certain growing conditions.

Table 3

Parameters of adaptability and stability of corn hybrids according to grain yield in the conditions of Arid Steppe (2017-2019)

\begin{tabular}{|l|c|c|c|c|c|c|c|}
\hline \multirow{2}{*}{ Cultivars } & \multicolumn{4}{|c|}{ Grain yield, t/ha } & \multicolumn{2}{c|}{$\begin{array}{c}\text { Parameters of plasticity } \\
\text { and stability }\end{array}$} \\
\cline { 2 - 9 } & $\begin{array}{c}\text { yield } \\
\text { under } \\
\text { irrigation }\end{array}$ & $\begin{array}{c}\text { yield } \\
\text { without } \\
\text { irrigation }\end{array}$ & $\begin{array}{c}\text { Min-max } \\
\text { under } \\
\text { irrigation }\end{array}$ & $\begin{array}{c}\text { Min-max } \\
\text { without } \\
\text { irrigation }\end{array}$ & $\begin{array}{c}\text { drought } \\
\text { resistance } \\
\text { coefficient }\end{array}$ & $b_{i}$ & $S_{d i}^{2}$ \\
\hline Stepovyi & 11,13 & 3,28 & $\begin{array}{c}10,38- \\
11,68\end{array}$ & $2,28-3,53$ & 0,29 & 0,94 & 0,25 \\
\hline DN Pyvykha & 11,02 & 3,05 & $\begin{array}{c}10,13- \\
11,53\end{array}$ & $2,25-3,28$ & 0,28 & 0,93 & 0,25 \\
\hline Skadovskyi & 10,95 & 2,57 & $9,88-11,82$ & $2,16-2,90$ & 0,23 & 0,99 & 0,77 \\
\hline DN Khotyn & 12,10 & 2,74 & $\begin{array}{c}10,03- \\
12,84\end{array}$ & $2,25-3,05$ & 0,22 & 1,01 & 1,33 \\
\hline Kakhovskyi & 12,65 & 2,13 & $\begin{array}{c}11,14- \\
13,70\end{array}$ & $1,55-2,45$ & 0,17 & 1,06 & 0,42 \\
\hline DN Rostok & 13,37 & 2,35 & $\begin{array}{c}11,92- \\
14,51\end{array}$ & $1,84-2,76$ & 0,18 & 1,23 & 0,29 \\
\hline Arabat & 14,19 & 1,81 & $\begin{array}{c}12,60- \\
16,04\end{array}$ & $1,36-2,16$ & 0,13 & 1,35 & 0,21 \\
\hline DN Sofia & 14,67 & 1,92 & $\begin{array}{c}13,03- \\
16,43\end{array}$ & $1,45-2,15$ & 0,13 & 1,28 & 0,46 \\
\hline
\end{tabular}

The regression coefficient of variety yield on the potential of the agro background under irrigation conditions, or the coefficient of plasticity $\left(b_{i}\right)$ is the most informative indicator of the response of genotypes to changes in environmental conditions. According to the coefficient of plasticity, the hybrids were divided into three groups.

- Homeostatic $\left(b_{i}<1\right)$ - hybrids that are characterized by a weak response to changes in growing conditions and provide stable yields under irrigation 
and without watering. This group includes hybrids Stepovyi, DN Pyvykha, Skadovskyi.

- Intensive type $\left(b_{i}>1\right)$ - highly plastic hybrids with high genetic potential, but with low stability of yield. This group includes hybrids DN Rostok, Arabat, Sofia. These hybrids have a very high potential yield (over $15 \mathrm{t} / \mathrm{ha}$ ), but require careful and timely technological operations under irrigation. Violations of technology or adverse weather factors dramatically reduce their yields. These varieties have the prospect of sowing mainly under the optimal irrigation regime and a sufficient level of mineral nutrition.

- Medium-plastic $\left(b_{i}=1\right)$ - hybrids with an adequate response rate to the improvement of growing conditions, which are quite restrained to respond to unstable weather conditions and fluctuations in the agro background. These are hybrids of DN Khotyn, Kakhovskyi. These hybrids have a fairly high yield potential and can be sown under different watering methods.

The most stable and predictable increases (decreases) in yield to change the eco-gradient have hybrids DN Rostok, Arabat, Sofia $\left(S_{d i}^{2}=0.29-0.46\right)$.

Summing up the results of research on grain yield, we can conclude that universal hybrids, adapted to a wide range of external conditions on each agroecological gradient, are inferior in productivity to genotypes with narrow adaptability. According to the adaptive properties should be distinguished: hybrids of intensive type with a strong reaction to the environment; homeostatic, providing stable yields under conditions of fluctuations in growing conditions; medium-plastic, adequately responding to changes in the level of the agro background.

To obtain high and stable yields of corn grain in each farm of the irrigated zone of the Dry Steppe, it is necessary to have a range of hybrids that have different types of reactions to irrigation methods and the level of moisture.

The realization of the productivity potential of corn hybrids is limited by various limited factors and one of the main ones is moisture supply. The adaptability of hybrids to the soil and climatic conditions of the Arid Steppe zone and artificial moisture supply is reflected in the parameters of the elements of the productivity structure, the main of which are the length of the cob, the length of the grained cob, the number of grain rows of cobs.

Table 4 shows the length paraments of the cob length in corn hybrids of different FAO groups with different moisture content and watering methods. On average, the smallest length of the cob was in the experiment without watering $15.8 \mathrm{~cm}$. Under watering, the length of the cob increased significantly and reached $19.3-19.7 \mathrm{~cm}$. Slightly longer the length was under the drip irrigation. Under irrigation conditions, the cob's length increased from precocious hybrids to late-ripening hybrids from $17.5 \mathrm{~cm}$ to $21.7 \mathrm{~cm}$. However, under natural moisture, cob elongation was much smaller and did not exceed $1.6 \mathrm{~cm}$. 
Table 4

\section{Morpho-metric indicators of cob structure and grain yield of corn hybrids of different FAO groups depending on irrigation methods and without irrigation (2017-2019)}

\begin{tabular}{|c|c|c|c|c|c|c|c|}
\hline $\begin{array}{l}\text { The } \\
\text { method of } \\
\text { moisture } \\
\text { supply }\end{array}$ & Hybrid & FAO & $\begin{array}{c}\text { Cob } \\
\text { length, } \\
\mathrm{cm}\end{array}$ & $\begin{array}{l}\text { Length } \\
\text { of the } \\
\text { grain } \\
\text { cob, cm }\end{array}$ & $\begin{array}{l}\text { Grain } \\
\text { index, } \\
\%\end{array}$ & $\begin{array}{l}\text { The number } \\
\text { of grain } \\
\text { rows of } \\
\text { cobs, pcs. }\end{array}$ & $\begin{array}{c}\text { Grain } \\
\text { yield, } \\
\text { t/ha }\end{array}$ \\
\hline \multirow{10}{*}{$\begin{array}{l}\text { Without } \\
\text { irrigation } \\
\text { (natural } \\
\text { moisture) }\end{array}$} & Stepovyi & 190 & 15,1 & 11,2 & 74,2 & 14,2 & 3,28 \\
\hline & Pyvykha & 180 & 14,7 & 10,7 & 72,8 & 14,1 & 3,05 \\
\hline & Skadovskyi & 290 & 15,4 & 9,6 & 62,3 & 14,1 & 2,57 \\
\hline & Khotyn & 280 & 15,8 & 9,8 & 62,0 & 14,3 & 2,74 \\
\hline & Kakhovskyi & 380 & 16,7 & 9,0 & 53,9 & 16,0 & 2,13 \\
\hline & Rostok & 340 & 16,0 & 10,3 & 64,4 & 16,0 & 2,35 \\
\hline & Arabat & 420 & 16,4 & 7,0 & 42,7 & 18,1 & 1,81 \\
\hline & Sofia & 420 & 16,3 & 7,2 & 44,2 & 18,2 & 1,92 \\
\hline & Average & & 15,8 & 9,3 & 58,8 & 15,6 & 2,48 \\
\hline & $\mathrm{HIP}_{05}$ & & 0,15 & 0,11 & - & - & 0,25 \\
\hline \multirow{10}{*}{$\begin{array}{l}\text { Irrigation } \\
\text { by } \\
\text { sprinkling }\end{array}$} & Stepovyi & 190 & 17,8 & 17,0 & 95,5 & 14,7 & 11,24 \\
\hline & Pyvykha & 180 & 17,5 & 16,7 & 95,4 & 14,3 & 11,04 \\
\hline & Skadovskyi & 290 & 17,9 & 17,1 & 95,5 & 14,4 & 11,34 \\
\hline & Khotyn & 280 & 18,4 & 18,0 & 97,8 & 15,6 & 11,63 \\
\hline & Kakhovskyi & 380 & 19,8 & 19,1 & 96,5 & 17,2 & 12,10 \\
\hline & Rostok & 340 & 19,7 & 19,2 & 97,5 & 17,3 & 12,22 \\
\hline & Arabat & 420 & 21,6 & 21,1 & 97,7 & 19,4 & 13,14 \\
\hline & Sofia & 420 & 21,8 & 21,0 & 96,3 & 19,6 & 13,43 \\
\hline & Average & & 19,3 & 18,6 & 96,4 & 16,6 & 12,02 \\
\hline & $\mathrm{HIP}_{05}$ & & 0,17 & 0,23 & - & - & 0,32 \\
\hline \multirow{10}{*}{$\begin{array}{l}\text { Drip } \\
\text { irrigation }\end{array}$} & Stepovyi & 190 & 18,1 & 18,0 & 99,4 & 14,8 & 11,46 \\
\hline & Pyvykha & 180 & 17,8 & 17,6 & 98,9 & 14,3 & 11,21 \\
\hline & Skadovskyi & 290 & 18,2 & 18,1 & 99,5 & 14,4 & 11,41 \\
\hline & Khotyn & 280 & 19,0 & 18,9 & 99,5 & 15,8 & 12,47 \\
\hline & Kakhovskyi & 380 & 20,4 & 20,2 & 99,0 & 17,4 & 13,22 \\
\hline & Rostok & 340 & 20,5 & 20,5 & 100,0 & 17,6 & 14,15 \\
\hline & Arabat & 420 & 21,8 & 21,7 & 99,5 & 19,5 & 15,23 \\
\hline & Sofia & 420 & 21,7 & 21,5 & 99,1 & 19,8 & 15,78 \\
\hline & Average & & 19,7 & 19,6 & 99,5 & 16,7 & 13,12 \\
\hline & $\mathrm{HIP}_{05}$ & & 0,27 & 0,31 & - & - & 0,41 \\
\hline \multirow{10}{*}{$\begin{array}{l}\text { Ground } \\
\text { irrigation }\end{array}$} & Stepovyi & 190 & 17,9 & 17,6 & 98,3 & 14,5 & 10,68 \\
\hline & Pyvykha & 180 & 17,5 & 17,3 & 98,9 & 14,3 & 10,81 \\
\hline & Skadovskyi & 290 & 17,9 & 17,6 & 98,3 & 14,2 & 10,12 \\
\hline & Khotyn & 280 & 18,7 & 18,6 & 99,5 & 15,7 & 12,19 \\
\hline & Kakhovskyi & 380 & 20,1 & 20,0 & 99,5 & 17,4 & 12,65 \\
\hline & Rostok & 340 & 20,3 & 20,2 & 99,5 & 17,7 & 13,74 \\
\hline & Arabat & 420 & 21,7 & 21,5 & 99,1 & 19,3 & 14,21 \\
\hline & Sofia & 420 & 21,6 & 21,3 & 98,6 & 19,7 & 14,81 \\
\hline & Average & & 19,5 & 19,3 & 98,9 & 16,6 & 12,40 \\
\hline & $\mathrm{HIP}_{05}$ & & 0,25 & 0,30 & - & - & 0,34 \\
\hline
\end{tabular}


Calculations of the dependence of cob length and grain yield in hybrids showed a high degree of positive association. The correlation coefficient (r) was +0.95 . The maximum level of productivity is reached at length of a cob over $21 \mathrm{~cm}$.

However, without irrigation, the relationship between cob length and yield had the opposite direction. The correlation coefficient was -0.884 , which indicates a significant loss of realized productivity potential in high-intensity hybrids. The results of correlation analysis showed that in the Dry Steppe without irrigation the potentially high yield of intensive type hybrids can be detrimental to real productivity, so it is necessary to select hybrids for production on the principle of adaptability to agri-environmental conditions.

It is known that the length of the cob is an indicator of the potential yield of corn grain. However, the cob is not always grained and in most cases it is the result of extreme abiotic factors. In our studies, the length of the cob was almost twice smaller than the length of the rod in non-irrigated conditions (see Table 4). Characteristically, the decrease in the length of the lake part was accompanied by an increase in potential productivity (increase in the length of the cob and the FAO group), which is the confirmation of the previous thesis about the inadequacy of intensive hybrid yields in extreme environments.

The length of the cob is the main indicator of yield both under irrigation and without watering. This is confirmed by the high correlations between the length of the grained cob and the grain yield $(r=0.907 \ldots 0.937)$.

A measure of the potential opportunities of corn hybrids may be the ratio of the grain part of the cob to the total length (see Tables). This indicator (Grain Index) is closely related to the adaptability of the hybrid to a particular technology and agri-environmental zone, so it can reflect the percentage of realization of the hybrid potential and serve as the "Index of realization of the yield potential".

Irrigation conditions under the optimal regime allow to almost fully realize the potential yield. Thus, in Rostock and Skadovsky hybrids, the realization of potential productivity reached $99.5-100 \%$ under drip irrigation. Drip irrigation provided the realization of potential productivity by $99.5 \%$. A slightly lower percentage of potential realization was provided by irrigation by sprinkling and ground irrigation (96.4 and 98.9\%, respectively). Without watering, the percentage of potential of hybrids was much lower and, importantly, decreased with increasing hybrid potential. This indicates the need to take into account an important technological indicator of hybrids such as the direction and level of genotype-environmental response, which is laid to the hybrid by special breeding programs.

Another important indicator of the potential productivity of corn hybrids is the number of grain rows of cobs. However, this indicator has a fairly high level of stability of manifestation in different agroecological conditions (see 
Tables). Since the cob has an even number of grain rows, the variation of their number in the hybrid can be within 2 rows. Growing conditions have almost no effect on the number of grain rows. It should be noted that the number of grain rows can serve as an indicator of the intensity of the hybrid.

High yield (over $15 \mathrm{t} / \mathrm{ha}$ ) can be provided by intensive type hybrids with 18-22 grain rows.

However, in the conditions of the Arid Steppe without irrigation, one should not expect a high yield from hybrids with 18-22 grain rows, as this trait is genetically determined and is characteristic of hybrids that require a high level of technological support. The level of dependence of the number of grain rows and yield indicates that with such a number of grain rows the yield level will not exceed $2 \mathrm{c} / \mathrm{ha}$. More drought-resistant hybrids have a number of grain rows of 14 and have genetically determined drought resistance.

It was found out that hybrids of FAO 180-290 (Stepovyi, Pyvykha, Skadovskyi), although they formed lower yields, but they had the greatest stability under different irrigation methods in the range of 10.12-11.46 t/ha. Grain yields of early-maturing hybrids were the highest without irrigation of 3.28 and $3.05 \mathrm{t} / \mathrm{ha}$, which indicates their high drought resistance. The use of these hybrids is expedient under the conditions of water-saving irrigation regimes on irrigated lands with low hydromodule and on rainfed massifs.

Among the hybrids of the middle-early maturity group (FAO 280-290), the best yield was the hybrid Khotyn (FAO 280), regardless of the method of watering. Under drip irrigation, its yield was $12.47 \mathrm{t} / \mathrm{ha}$. Irrigation by sprinkling and subsoil irrigation reduced yields by 0.84 and $0.28 \mathrm{t} / \mathrm{ha}$, which is due to the greater opportunities for rapid wetting of the surface layer of the soil under drip irrigation during drought-critical growing seasons.

Hybrids of the medium-ripe group Kakhovskyi and Rostok also had the highest grain yield under drip irrigation 13.2 and $14.15 \mathrm{t} / \mathrm{ha}$. The decrease in yield under other irrigation methods ranged from 0.41 to $1.93 \mathrm{t} / \mathrm{ha}$. The greatest advantages of the drip irrigation method were recorded in the midlate hybrids Arabat and Sofia, for which the yield reached 15.23 and $15.78 \mathrm{t} / \mathrm{ha}$. Yields were higher by $1.02-2.35 \mathrm{t} / \mathrm{ha}$ compared to other irrigation methods. This reaction of medium-late hybrids with FAO 420-430 is explained by the fact that the moisture consumption of hybrids with a longer growing season by $70-80 \%$ is provided by irrigation water. During the period of the greatest evapotranpiration (July-August), the daily water consumption of corn in the Arid Steppe exceeds $100 \mathrm{~m}^{3} /$ ha and this amount of water can be provided by drip irrigation daily. Irrigation by sprinkling by installations of frontal or circular action can provide the next watering with the minimum term of 4-5 days that can be late and, as a result, the optimum level of humidity is broken. Irrigation by soil method is carried out by laying an irrigation tape to a depth of $30 \mathrm{~cm}$ of soil profile. Moistening of the surface 
layer of the soil is carried out by raising the irrigation water along the capillary border, which also does not provide the optimal level of moistening of the surface layer of the soil $0-10 \mathrm{~cm}$.

An important indicator of the adaptability of hybrids to agroecological conditions is the weight of grain from the cob. Table 5 shows the results of accounting for the mass of grain from the cob in modern innovative corn hybrids with different methods of irrigation and without irrigation. The grain weight of the upper cob is shown, because in modern corn hybrids only one (upper) cob is formed productively at the optimal plant density, and the cob from the lower internode is formed slightly grained or not grained (except for liquefied crops).

Table 5

Grain cob weight (g) in corn hybrids of different FAO groups depending on watering methods and without irrigation (2017-2019)

\begin{tabular}{|l|c|c|c|c|c|}
\hline \multicolumn{1}{|c|}{ Hybrid } & FAO & $\begin{array}{c}\text { Without } \\
\text { irrigation }\end{array}$ & $\begin{array}{c}\text { Irrigation by } \\
\text { sprinkling }\end{array}$ & $\begin{array}{c}\text { Drip } \\
\text { irrigation }\end{array}$ & $\begin{array}{c}\text { Ground } \\
\text { irrigation }\end{array}$ \\
\hline Stepovyi & 190 & 102,3 & 152,6 & 158,3 & 149,8 \\
\hline DN Pyvykha & 180 & 98,3 & 149,4 & 154,3 & 145,2 \\
\hline Skadovskyi & 290 & 96,4 & 156,2 & 158,7 & 153,4 \\
\hline DN Khotyn & 280 & 97,5 & 173,5 & 178,4 & 172,0 \\
\hline Kakhovskyi & 380 & 67,4 & 185,8 & 195,3 & 190,7 \\
\hline DN Rostok & 340 & 65,4 & 196,1 & 208,7 & 201,3 \\
\hline Arabat & 420 & 41,5 & 200,5 & 214,8 & 207,1 \\
\hline DN Sofia & 420 & 42,0 & 207,2 & 217,1 & 211,3 \\
\hline Average & & 76,35 & 177,6 & 185,7 & 178,8 \\
\hline HIP $_{05}$ & & 3,14 & 5,23 & 5,45 & 4,89 \\
\hline
\end{tabular}

Under irrigation conditions, the weight of cob grain in corn hybrids increased with the increase of the FAO group, which is quite natural. It reached its maximum values in the mid-late hybrids Arabat and Sofia (200-217 g). More favorable conditions for cob formation were, on average, by drip irrigation and ground irrigation methods (average cob grain weight 185.7 and $178.8 \mathrm{~g}$ ). However, precocious and medium-ripe hybrids formed a larger cob mass under drip irrigation and sprinkling, and FAO 300-420 hybrids formed larger cobs under drip and subsoil irrigation. This is due to the fact that hybrids with increased duration of the growing season have a stronger root system, which penetrates to the depth of the irrigation strip and the rise of the capillary border just in the phase of organogenesis formation of potential productivity of the cob. Irrigation water enters the root system of precocious hybrids with ground watering with a delay, which leads to incomplete realization of potential opportunities for cob formation. However, without irrigation, the weight of grain from the cob decreased sharply under non- 
irrigated conditions. This is due to the fact that in late-maturing hybrids, despite the higher potential productivity of the cob, in drought conditions there was a suppression of pollination of the upper part of the rod and the formation of low grain weight of the cob.

Calculations of the dependence of grain yield of corn hybrids on the weight of cob grain under irrigation conditions showed that there is a strong positive relationship between these indicators. Characteristically, the dependence tends to be straightforward, the correlation coefficient was at a high level of +0.938 . The maximum grain yield is fixed on the weight of the cob grain in the range of $200-220 \mathrm{~g}$, which ensures the grain yield of corn hybrids under irrigation conditions of $15-16 \mathrm{t} / \mathrm{ha}$.

The dependence of grain yield and cob grain weight without irrigation was similar, however, at a much lower level of cob yield and grain weight. The maximum grain yield in the range of 3-3.5 t/ha is formed by the weight of grain from the cob 90-110 g, which is almost twice less than under irrigation conditions. It should be noted that under irrigation conditions can form the second cob, less productive, however, with the liquefaction of the density of the phytocenosis, the second cob can compensate for the overall grain yield. Without irrigation of maize hybrids, the second (lower) cob can be formed, but no grain is formed on it. The correlation coefficient was at a high level -0.928 , which indicates the predominant dependence of grain yield of corn hybrids, both with watering and without irrigation, on the weight of cob grain.

This dependence allows, to some extent, to predict visually the potential yield of corn hybrids by cob grain weight. The maximum value of the grain weight of the cob during the growing season of hybrids is 118-122 days, which corresponds to the maturity group according to FAO 400-420.

In the conditions of bogar, or violation of the optimal irrigation regime, a visual forecast of yield by weight of the cob is also possible. However, it should be borne in mind that the productivity of the corn hybrid plant will be a priori lower with increasing FAO group. There is a sharp decline in plant productivity (grain weight of the cob) with increasing duration of vegetation. The correlation coefficient is -0.931 . Therefore, under non-irrigated conditions of the Arid Steppe to obtain the productivity of the cob (grain weight) within 95-110 g per plant, it is necessary to focus on hybrids with a growing season of 90-100 days, which have significantly less water consumption and high genotypic drought resistance.

The weight of 1000 grains is important for the formation of grain yields of corn hybrids and its consumer properties.

In our studies, this indicator under irrigation ranged from 240 to $315 \mathrm{~g}$ (Table 6). Irrigation methods did not have a significant effect on grain size, on average, a slightly larger mass of 1000 grains was formed by drip irrigation and subsoil 295.8 and $296.3 \mathrm{~g}$ against $285.7 \mathrm{~g}$ by sprinkling. 
However, there was a significant difference in maturity groups. The mass of 1000 grains was much larger in precocious forms under drip and subsoil irrigation. This is due to the fact that the formation and pouring of grains in precocious hybrids takes place in the driest hot growing season (the second half of July - first half of August). During this period, sprinkling is not always possible to relieve the stress of drought, which affects the smaller grain size. Hybrids with an increased duration of the growing season also have a stronger root system, which penetrates to the depth of the irrigation belt and the rise of the capillary border and gives greater buffering response to these hybrids to the extreme effects of heat. A significant factor in the formation of grain size was the group of FAO hybrids. The weight of 1000 grains reached $313-316 \mathrm{~g}$ in FAO 420 hybrids, and decreased to $240-270 \mathrm{~g}$ in FAO 180-190 hybrids. This is due to the smaller number of grain rows of cobs in early-maturing hybrids and the affiliation of the grain type to siliceous-toothed, which have a genetically determined lower grain weight.

The weight of 1000 grains in hybrids of different maturity groups without watering had much lower indicators compared to irrigation conditions and ranged from 150 to $190 \mathrm{~g}$. A characteristic feature of this peculiarity is that larger grain sizes had drought-resistant hybrids Stepovyi, Pyvykha, Khotyn. This is due to the fact that hybrids of the intensive type may have cobs with a large number of pollinated female flowers (up to 1000 potential grains), however, in the process of grain formation and filling more moisture deficiency, which leads to reduction of pollinated flowers and grain tenderness. due to the violation of the reutilization of nutrients and their attraction from the leaf mass to the grain.

Table 6

Weight of 1000 grains in corn hybrids (g) depending on the methods of watering and without irrigation (2017-2019)

\begin{tabular}{|l|c|c|c|c|c|}
\hline \multicolumn{1}{|c|}{ Hybrid } & FAO & $\begin{array}{c}\text { Without } \\
\text { irrigation }\end{array}$ & $\begin{array}{c}\text { Irrigation by } \\
\text { sprinkling }\end{array}$ & $\begin{array}{c}\text { Drip } \\
\text { irrigation }\end{array}$ & $\begin{array}{c}\text { Ground } \\
\text { irrigation }\end{array}$ \\
\hline Stepovyi & 190 & 190,2 & 240,5 & 256,4 & 255,6 \\
\hline DN Pyvykha & 180 & 174,8 & 242,0 & 270,3 & 275,0 \\
\hline Skadovskyi & 290 & 165,4 & 280,0 & 294,7 & 296,2 \\
\hline DN Khotyn & 280 & 175,3 & 291,4 & 298,9 & 298,3 \\
\hline Kakhovskyi & 380 & 160,1 & 301,7 & 306,4 & 307,8 \\
\hline DN Rostok & 340 & 157,4 & 302,5 & 308,8 & 310,3 \\
\hline Arabat & 420 & 156,2 & 313,4 & 316,1 & 314,0 \\
\hline DN Sofia & 420 & 168,4 & 314,7 & 315,3 & 313,9 \\
\hline Average & & 168,4 & 285,7 & 295,8 & 296,3 \\
\hline HIP $_{05}$ & & 5,2 & 6,3 & 7,1 & 6,5 \\
\hline
\end{tabular}


Calculations of the dependence of grain size and yield of corn hybrids under irrigation conditions showed that the increase in yield is facilitated by increasing the mass of 1000 grains. However, there are certain optimums for the mass of 1000 grains. Thus, it was found that the yield of hybrids in the range of 15-16 t/ha can be formed by the mass of 1000 grains at the level of 310-320 g. The correlation coefficient between these indicators was 0.733, which indicates a strong dependence of grain yield and grain size of maize hybrids irrigation.

The same dependence was observed in non-irrigated conditions. The correlation coefficient between grain yield and the mass of 1000 grains was 0.834. In the conditions of the Arid Steppe without watering to receive grain productivity of hybrids of corn it is possible only at achievement of weight of 1000 grains over $175 \mathrm{~g}$.

\section{CONCLUSIONS}

The retrospective analysis of the yield of the main grain crops in the Arid Steppe zone over a 130-year period showed that the highest rates of yield growth were recorded for corn. The annual increase in yield was $31 \mathrm{~kg} / \mathrm{ha}$ per year and this was due to the use of new varieties (hybrids) and improved cultivation technologies. Irrigation provided an opportunity to realize the potential yield of new hybrids and increase yields from 6.59 to $82.3 \mathrm{c} / \mathrm{ha}$. Yields increased 12.5 times with an annual increase of $58 \mathrm{~kg} / \mathrm{ha}$ per year.

Modern corn hybrids, created for irrigation conditions, must be provided to production with certain parameters of technological requirements. This is especially true of irrigation regimes and irrigation methods. Studies conducted under different methods of irrigation and without irrigation in the Arid Steppe made it possible to provide production parameters of adaptability of certain hybrids to specific agroecological and technological features.

Maize hybrids had the highest grain yield under drip irrigation. The decrease in yield under other irrigation methods ranged from 0.41 to $2.35 \mathrm{t} / \mathrm{ha}$. The greatest advantages of the drip irrigation method were recorded in the mid-late hybrids Arabat and DN Sofia, their yield was 15.23 and $15.78 \mathrm{t} / \mathrm{ha}$ and was higher by $1.02-2.35 \mathrm{t} / \mathrm{ha}$ compared to other irrigation methods.

Morpho-metric traits of cob (cob length, cob length, grain cob share, number of grain rows) have a significant but divergent effect on grain yield in modern domestic corn hybrids with different methods of watering and moisture supply in Ukraine.

In the Arid Steppe without irrigation, the potentially high yield of intensive type hybrids can be detrimental to actual productivity, so it is necessary to select hybrids for production on the principle of adaptability to agrienvironmental conditions. 
The length of the cob is the main indicator of yield both under irrigation and without watering. This is confirmed by high correlation coefficients between the length of the cob and the grain yield $(r=0.907 \ldots 0.931)$. A measure of the potential of maize hybrids can be the ratio of the grain part of the cob to the total length of the rod (grain size index). This indicator is related to the adaptation of the hybrid to a particular technology and agrienvironmental zone, so it can reflect the percentage of realization of the potential of the hybrid and also serve as an "Index of realization of the yield potential".

Under irrigation conditions, it is necessary to use corn hybrids with a genetically programmed response to growing conditions (optimal soil moisture and mineral nutrition). Violation of moisture supply of corn crops leads to significant losses of grain yield, especially in hybrids of the late group.

\section{SUMMARY}

The aim is to establish the yield structure and adaptability parameters of modern domestic corn hybrids under different methods of watering and moisture in the Arid Steppe and to determine the dynamics of growth of grain yields in the south of Ukraine. The methods of the research are field, laboratory, statistical and retrospective methods. Results. A retrospective analysis of the yield of the main grain crops in the Arid Steppe zone over a 130 -year period showed that the highest rates of yield growth were recorded for corn. The annual increase in yield was $31 \mathrm{~kg} / \mathrm{ha}$ per year and this was due to the use of new varieties (hybrids) and improved cultivation technologies. Irrigation provided an opportunity to realize the potential yield of new hybrids and increase yields from 6.59 to $82.3 \mathrm{c} /$ ha. Yields increased 12.5 times with an annual increase of $58 \mathrm{~kg} / \mathrm{ha}$ per year. Corn hybrids had the highest grain yield under drip irrigation. The decrease in yield under other irrigation methods ranged from 0.41 to $2.35 \mathrm{t} / \mathrm{ha}$. The greatest advantages of the drip irrigation method were recorded in the mid-late hybrids Arabat and DN Sofia, their yield was 15.23 and $15.78 \mathrm{t} / \mathrm{ha}$ and was higher by $1.02-2.35 \mathrm{t} / \mathrm{ha}$ compared to other irrigation methods. Morpho-metric traits of cob (cob length, grained cob length, grain cob share, number of grain rows) have a significant but divergent effect on grain yield in modern domestic maize hybrids with different methods of watering and moisture supply in Ukraine. The length of the cob is the main indicator of yield both under irrigation and without watering. This is confirmed by high correlation coefficients between the length of the cob and the grain yield $(r=0.907 \ldots 0.931)$. A measure of the potential of corn hybrids can be the ratio of the grain part of the cob to the total length of the rod (grain size index). Conclusions. Under irrigation conditions, it is necessary to use maize hybrids with a genetically 
programmed response to growing conditions (optimal soil moisture and mineral nutrition). Violation of moisture supply of corn crops leads to significant losses of grain yield, especially in hybrids of the late group.

\section{REFERENCES}

1. Tester M., Langridge P. Breeding technologies to increase crop production in a changing World. Science. 2010. Vol. 327. Iss. 5967. P. 818-822. DOI : 10.1126/science.1183700.

2. Gilliham M., Able J.A., Roy S.J. Translating knowledge about abiotic stress tolerance to breeding programmers. Plant Journal. 2017. Vol. 90. Iss. 5. P. 898-917. DOI : 10.1111/tpj.13456.

3. Розвиток агарної сфери економіки в умовах децентралізації управління в Україні / Я.М. Гадзало та ін. Київ : Аграрна наука, 2018. $328 \mathrm{c}$.

4. Productivity and adaptability of Myronivka spring barley varieties of different breeding periods / B.M. Гудзенко та ін. Plant Varieties Studying and Protection. 2018. № 14(2). C. 190-202. DOI : org/10.21498/25181017.14.2.2018.134766.

5. Дзюбецький Б.В., Черчель В.Ю. Урожайність зерна скоростиглих гібридів кукурудзи різних сортозмін. Вісник аграрної науки. 2017. № 8. C. $19-23$.

6. Марченко Т.Ю., Нужна М.В., Боденко Н.А. Моделі гібридів кукурудзи FAO 150-490 для умов зрошення. Plant Varieties Studying and Protection. 2018. T. 14. № 1. C. 58-64. DOI : 10.21498/2518-1017.14.1. 2018.126508.

7. Food and Agriculture Organization of the United Nations. URL : http://www.fao.org/faostat/en/\#data/QC.

8. United States Department of Agriculture. Foreign Agricultural Service. URL : http://www.usda crop explorer: global crop production analysis.

9. Troyer A.F. Adaptedness and heterosis in corn and mule hybrids. Crop science, 2006. V. 46. № 2. P. 528-543. DOI :10.2135/cropsci2005.0065.

10. Vozhegova R.A., Hlushko T.V. Productivity of maize hybrids of different fao groups depending on condition of irrigation and dosage of fertilizers in the southern steppe of Ukraine. Agricultural Science and Practice. 2014. № 1(3). P. 62-68.

11. Оцінка показників стабільності й пластичності нових гібридів кукурудзи (Zea mays L.) в умовах Полісся та Степу України / Л.М. Присяжнюк та ін. Plant Varieties Studying and Protection. 2016. № 2. C. 16-21. DOI : 10.21498/2518-1017.2(31).2016.70050.

12. Наукові основи агропромислового виробництва в зоні Степу України / М.В. Зубецьта ін. Київ : Аграрна наука, 2010. 765 с. 
13. Assessment of the CROPWAT 8.0 software reliability for evapotranspiration and crop water requirements calculations / R.A. Vozhehova et al. Journal of Water and Land Development. Polish Academy of Sciences (PAN) in Warsaw. 2018. № 39 (X-XII). P. 147-152. DOI : 10.2478/jwld-2018-0070.

14. Вожегова Р.А., Малярчук М.П., Коковіхін С.В. Методика польових і лабораторних досліджень на зрошуваних землях. Херсон : Грінь Д.С., 2014. $286 \mathrm{c}$.

15. Ушкаренко В.О., Голобородько С.П., Коковіхін С.В. Методика польового досліду (зрошуване землеробство). Херсон : Грінь Д.С., 2014. $448 \mathrm{c}$.

16. Eberhart S.A., Russell W.A. Stability parameters for comparing varieties. Crop Science. 1966. Vol. 6. № 1. P. 36-40.

17. Науково-практичні рекомендації 3 технології вирощування кукурудзи в умовах зрошення Південного Степу України / Р.А. Вожегова та ін. Херсон : Грінь Д.С., 2015. 104 с.

18. Исторический очеркъ деятельности Херсонскаго Губернскаго Земства за 1865-1899 гг. Выпускъ III. Издание Херсонсой Губернской земской Управы. Херсонъ, 1906. 276 с.

\section{Information about authors: Ivaniv M. O.,}

Candidate of Agricultural Sciences, Associate Professor at the Department of Mechanization and Life Safety

Kherson State Agrarian University 23, Stretenska str., Kherson, 73006, Ukraine Lavrynenko Yu. O., Doctor of Agricultural Sciences, Professor, Corresponding Member of the National Academy

Agrarian Sciences of Ukraine, Deputy Director for Research Institute Irrigated Agriculture of the National Academy Agrarian Sciences of Ukraine Naddnipryanske sett., Kherson, 73483, Ukraine 